\title{
The detection of avocado sunblotch viroid in avocado using a real-time reverse transcriptase polymerase chain reaction
}

\author{
Gabriel Morey-León ${ }^{1,2,3 *}$, Eddy Ortega-Ramirez ${ }^{2,4}$, Carmen Julca-Chunga ${ }^{2}$, Cesar Santos-Chanta ${ }^{2}$, \\ LISSETTE GRATEROL-CALDERA ${ }^{3}$, ERIC MIALHE ${ }^{5}$ \\ ${ }^{1}$ Faculty of Medicine, University of Guayaquil, Guayaquil, Ecuador \\ ${ }^{2}$ Biotec C.M.C. Research and Development Center, D\&C Group, Lima, Peru \\ ${ }^{3}$ Camposol S.A., Lima, Peru \\ ${ }^{4}$ Molecular Microbiology and Biotechnology Laboratory, National University of San Marcos, Lima, Peru \\ ${ }^{5}$ INCABiotec S.A.C., Tumbes, Peru
}

\begin{abstract}
The sunblotch disease is one of the diseases that affects avocado (Persea americana Mill) crops in particular, causing serious crop losses. The causal agent is the avocado sunblotch viroid (ASBVd), a circular RNA-based pathogen built of 247 nucleotides, which causes stem discoloration, bleaching, variegation, and distortion on the leaves and sunken yellow or red blotches on the fruits. In this study, a novel SYBR green-based real-time RT-PCR (RT-qPCR) assay specific for ASB viroid was developed. The assay was followed by a standard curve and a melting curve analysis for the detection, identification, and quantification of the full-length ASB viroid. The assay's lower limit of detection in the samples of avocado leaves was 8.8 copies/ $\mu$ l. The RT-qPCR was 100 times more sensitive to ASBVd than the conventional RT-PCR. The melting curve analysis showed a variation in the specific melting temperature $(\mathrm{Tm})$ between positive samples, probably due to the alteration in the nucleotide sequences of viroids. In conclusion, the use of RT-qPCR assays established in this study, as a routine diagnostic method in breeding programs, could decrease the viroid incidence in avocado crops and its further accumulation in plants.
\end{abstract}

Key words: Persea americana, avocado sunblotch viroid, RNA-based pathogen, real-time RT-PCR, sensitivity, specificity.

\section{Introduction}

Avocado sunblotch viroid (ASBVd), a member of $A_{v}$ sunviroidae family (Flores et al., 2000a; Flores et al., 2000b; Flores et al., 2004), is a small, circular, globally distributed RNA-based pathogen of 247 nucleotides in length (Palukaitis et al., 1979; Hutchins et al., 1986; Daròs et al., 1994). The viroid induces the sunblotch disease (Dale et al., 1982; Desjardins, 1987) causing characteristic symptoms such as stem discoloration, bleaching, variegation, and distortion on the leaves and sunken yellow or red blotches on the fruits (Semancik and Szychowski, 1994). The pathogen reduces crop yields by 18-95\% (Wallace and Drake 1962; Vargas et al., 1991; Lemus et al., 2005; Grozo et al., 2006). ASBVd is trans- mitted by the grafting of infected budwoods, pollen, and seeds, but it has no known vector (Mathews et al., 1997).

Currently, diagnostic techniques such as nucleic acid hybridization and reverse transcription coupled with polymerase chain reaction (RT-PCR) have become a common practice for the detection of viroids because of their relative simplicity and high sensitivity when compared with conventional diagnostic methods such as biochemical indexing, in situ hybridization, polyacrylamide gel electrophoresis (PAGE), and nucleic acid spot hybridization (Allen and Dale, 1981; Mackenzie et al., 1997; Bernard and Duran-Vila, 2006; Fekih Hassen et al., 2006; Hajizadeh et al., 2012). However, the con-

\footnotetext{
* Corresponding author: Faculty of Medicine, University of Guayaquil, Guayaquil, Ecuador; e-mail: gabriel.moreyl@ug.edu.ec
} 
ventional RT-PCR procedure for detecting ASBVd leads to false-negative results due to primer dimer formation, the presence of samples with low viroid levels, and unequal distribution of viroids throughout the plants. Because of these issues, certification programs that verify pathogen-free status are not maximally effective, and may thus permit the pathogen to infect new avocado plantations and areas.

A rapid, sensitive, and quantitative method for monitoring the viroid replication and translocation throughout plant tissues, with increased capacity to avoid falsenegative results, is necessary to support both basic research and field applications. Real-time RT-PCR (RTqPCR) has shown high sensitivity in the viroid detection in many previous studies (Boonham et al., 2004; Roenhorst et al., 2005; Tessitori et al., 2005; Ruiz-Ruiz et al., 2007; Rizza et al., 2009; Monger et al., 2010; Luigi et al., 2011; Parisi et al., 2011, Botermans et al., 2013). In this study, we developed a real-time RT-PCR assay based on SYBR Green I for the absolute quantification of ASBVd in avocado samples.

\section{Methods}

\section{Sample collection}

Plant samples used in this study consisted of Hass avocado (Persea americana, Mill) leaves collected from symptomatic and asymptomatic trees in Peruvian noncommercial avocado crops in La Libertad, Peru. Five leaves from each of 390 avocado trees (10 symptomatic and 380 asymptomatic) of 19 plots in 5 different areas were sampled. Leaf age can affect the symptom expression and prevent RNA extraction (Suzuki et al., 2001); therefore, leaves were taken from the middle to the top of the tree to avoid collection of older leaves near the bottom. Leaves from in vitro Hass avocado ASBVd-free plants were used as a negative control.

\section{RNA extraction and cDNA synthesis}

Viroid RNA from leaf samples ( $250 \mathrm{mg})$ was isolated following a previously described protocol (Chang et al., 1993). The extracted RNA was eluted in $11 \mu \mathrm{l}$ of nuclease-free water and stored at $-80^{\circ} \mathrm{C}$ until use. $A$ viroid RNA obtained from the sample of a symptomatic tree, previously confirmed by RT-PCR in a reference laboratory, was used as a positive control. The cDNA was synthesized in a $25 \mu \mathrm{l}$ reverse transcription reaction containing $1 \mu \mathrm{g}$ of RNA template, $1 \mathrm{X}$ RT buffer $(250 \mathrm{mM}$ Tris- $\mathrm{HCl} \mathrm{pH}$ 8.3, $375 \mathrm{mM} \mathrm{KCl}, 15 \mathrm{mM} \mathrm{MgCl} 2,50 \mathrm{mM}$ DTT), $1.25 \mu \mathrm{M}$ of each primer (ViroidR, ASBVd2qPCR$\mathrm{R}$, and ActR), $0.5 \mathrm{mM}$ of dNTPs, $20 \mathrm{U}$ of Ribolock RNase Inhibitor (Fermentas, Thermo Scientific, Waltham, MA USA), 200 U of Maxima Reverse Transcriptase (Fermentas, Thermo Scientific, Waltham, MA, USA). A reverse transcription reaction was conducted at $55^{\circ} \mathrm{C}$ for $55 \mathrm{~min}$.

\section{ABSVd detection using PCR and quantification by $R T-q P C R$}

The specific primers taken from Schnell and coworkers (1997) and Schnell and coworkers (2001) were used for ASBVd detection by end-point PCR. The ASBVd2qPCR-F and ASBVd2qPCR-R primers for the quantification of ASBVd by RT-qPCR were designed using the online Primer3 version 4.0 software (http:// bioinfo.ut.ee/primer3-0.4.0/). Primer ActF and ActR of $\beta$-actin were used as internal controls (Brunner et al., 2004).

The end-point PCR was carried out in a $50 \mu \mathrm{l}$ reaction mixture containing $1 \mu \mathrm{l} \mathrm{cDNA}, 25 \mu \mathrm{l}$ PCR master mix $(2 \times)$ (Fermentas, Thermo Scientific, Waltham, MA USA), $1 \mu \mathrm{l}(0.4 \mu \mathrm{M})$ of both primers, and $22 \mu \mathrm{l}$ of Ultrapure water (Invitrogen, USA). cDNA from samples was amplified using the following conditions: $95^{\circ} \mathrm{C}$ for $4 \mathrm{~min}$, then 35 cycles at $95^{\circ} \mathrm{C}$ for $30 \mathrm{~s}, 55^{\circ} \mathrm{C}$ for $30 \mathrm{~s}$, and $72^{\circ} \mathrm{C}$ for $30 \mathrm{~s}$. All PCR reactions were conducted in triplicate and the products were analyzed on a $3 \%$ agarose gel in $1 \times$ TAE buffer to confirm the specificity of the reaction.

Real-time RT-PCR reactions were set up using a total volume of $15 \mu \mathrm{l}$ containing $1 \mu \mathrm{l}$ of cDNA, $7.5 \mu \mathrm{l} 2 \times$ LightCycler 480 SYBR Green I Master (Roche Diagnostic $\mathrm{GbH}$, Germany), $1.0 \mu \mathrm{l}(0.6 \mu \mathrm{M})$ of each primer, and $4.5 \mu \mathrm{l}$ of DNase/RNase-free distilled water (Life Technologies, USA). Real-time PCR experiments were run on a LightCycler 480 Instrument II (Roche Diagnostics, Mannheim, Germany) after activation of the hot start enzyme for $5 \mathrm{~min}$ at $95^{\circ} \mathrm{C}$, followed by 40 cycles of $10 \mathrm{~s}$ at $95^{\circ} \mathrm{C}, 10 \mathrm{~s}$ at $62^{\circ} \mathrm{C}$, and $10 \mathrm{~s}$ at $72^{\circ} \mathrm{C}$. Amplification signals were detected during the annealing step of each cycle at $62^{\circ} \mathrm{C}$, using a SYBR Green I (483 $-533 \mathrm{~nm}$ ). For the melting curve analysis, after the PCR machine was heated, the reaction mixtures were kept at $95^{\circ} \mathrm{C}$ for $1 \mathrm{~min}$, allowed to cool at $55^{\circ} \mathrm{C}$ for $1 \mathrm{~min}$, and then slowly heated again to $95^{\circ} \mathrm{C}$ at a ramp rate of $0.06^{\circ} \mathrm{C} / \mathrm{s}$. Continuous fluorescence was acquired at the 
Table 1. The sequences of primers used for ASBVd detection and quantification by RT-PCR and RT-qPCR

\begin{tabular}{l|l|l}
\hline \multicolumn{1}{c|}{ Primer name } & \multicolumn{1}{|c}{ Sequence $\left(5^{\prime}-3^{\prime}\right)$} & \multicolumn{1}{c}{ References } \\
\cline { 1 - 2 } Viroid-F & AAGTCGAAACTCAGAGTCGG & \multirow{2}{*}{ Schnell et al. (1997) } \\
\cline { 1 - 2 } Viroid-R & GTGAGAGAAGGAGGAGT & \\
\hline ASBVd2qPCR-F & TGTTCCGACTTTCCGACTCT & \multirow{2}{*}{ this study } \\
\hline ASBVd2qPCR-R & AAACCTTGCGAGACTCATCA & \\
\hline ACT-2F & CCCATTGAGCACGGTATTGT & \multirow{2}{*}{ Brunner et al. (2004) } \\
\hline ACT-2R & TACGACCACTGGCATACAGG & \\
\hline
\end{tabular}

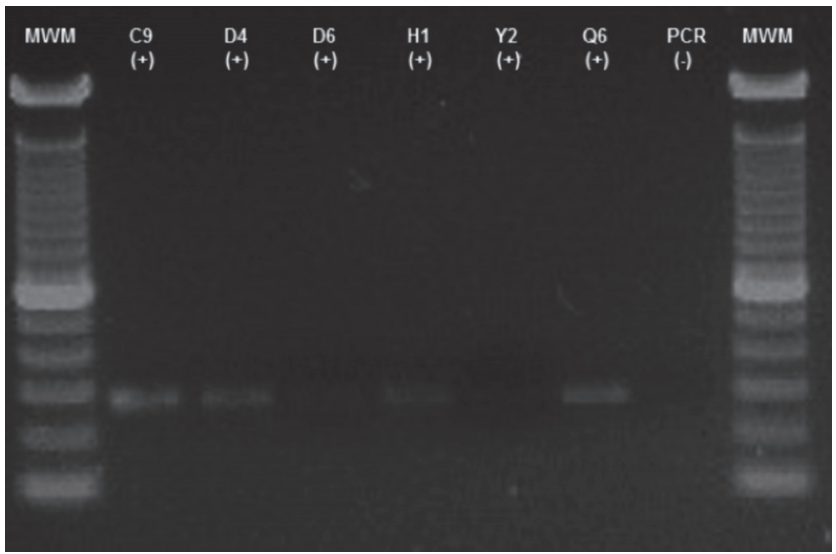

Fig. 1A. RT-qPCR assay for ASBVd detection in leaf samples; migration of positive detection of ASBVd by RT-qPCR in avocado leaves: D4, D6, H1, Y2 (asymptomatic), C9, Q6 (symptomatic) samples show the specific product $249 \mathrm{nt}$; PCR (-) - negative control (RNA from ASBVd-free plant); MWM - Molecular Weight Marker

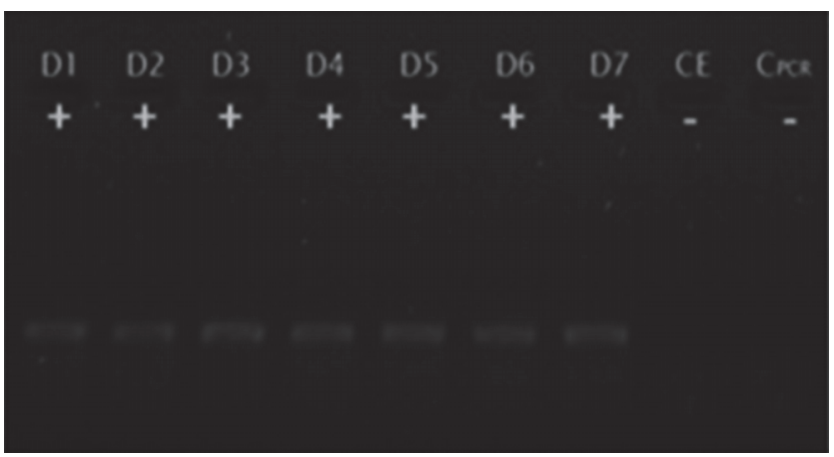

Fig. 1B. $\beta$-actin amplification of different avocado leaves samples (D1-D7) used as an internal control (219 nt), CE - extraction negative control, CPCR - PCR negative control (RNA from a bacterial sample), MPM - Molecular Weight Marker

indicated wavelengths. The RT-qPCR products were analyzed on a $3 \%$ agarose gel in $1 \mathrm{X}$ TAE buffer to confirm their specificity.

\section{Sequencing}

Amplicons, obtained in the RT-PCR and RT-qPCR, were directly sequenced after purification. Aliquots of $40 \mu \mathrm{l}$ of each amplicon were purified with the Qiamp PCR purification kit (Qiagen, Hilden, Germany) and sequenced using the BigDye Terminator Cycle Sequence Kit v3.1 in an ABI3130xl automated sequencer (Applied Biosystems, USA) using ViroidR and ASBVd2qPCR-R primers. The obtained nucleotide sequences were subjected to the basic local alignment search tool (BLAST) (www.ncbi.nlm.nih.gov/blast).

\section{Detection limit and the standard curve}

A log-10 dilution series of ASBVd artificial template (plasmid) was done in Ultrapure water (Thermo Fisher Scientific, USA) containing an initial concentration of $6.37 \mathrm{E}+08$ copies $/ \mu 1$. Serial dilutions were then evaluated in triplicate by using the optimized RT-qPCR assay in order to determine its analytical sensitivity and repeatability. PCR standard curves were generated by analyzing the crossing point $(\mathrm{Cp})$ values acquired from the LightCycler 480 instrument II with LightCycler 480 software release 1.2.0.0625, version 1.2.0.169.

The detection limit of the RT-qPCR and RT-PCR assays was determined by testing 2 serial 10-fold dilutions of the in vitro transcribed viroid RNA ranging from $10^{5}$ to $10^{0}$ copies $/ \mu$ l. The results from both assays were compared to determine the most sensitive assay.

\section{Detection of ASBVd from avocado leaves}

Leaves samples from 380 asymptomatic avocado trees (Persea americana Mill) located in La Libertad, Peru, were evaluated for the detection and quantification of ABSVd using the RT-qPCR assay described above. 


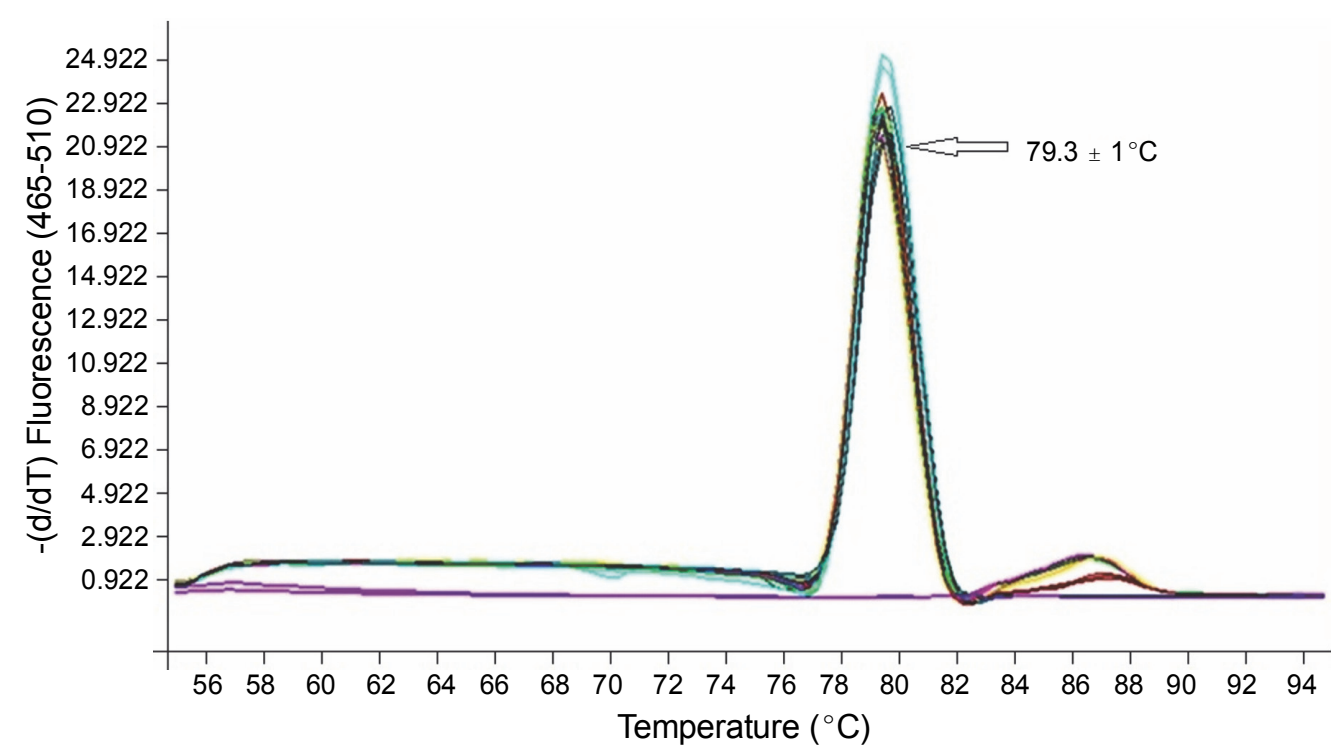

Fig. 2. Melting curve analysis of RT-qPCR assay for ASBVd detection of symptomatic sample. The positive sample shows the specific peaks at $79.3 \pm 1{ }^{\circ} \mathrm{C}$ (lines green, red, gray, yellow, brown and turquoise), negative samples (water and RNA from ASBVdfree plant) do not show peak (violet lines). The X-axis shows the melting temperature and the Y-axis derivate intensity of fluorescence - $(\mathrm{d} / \mathrm{dT})$ from SYBR Green dye in the melting temperature process
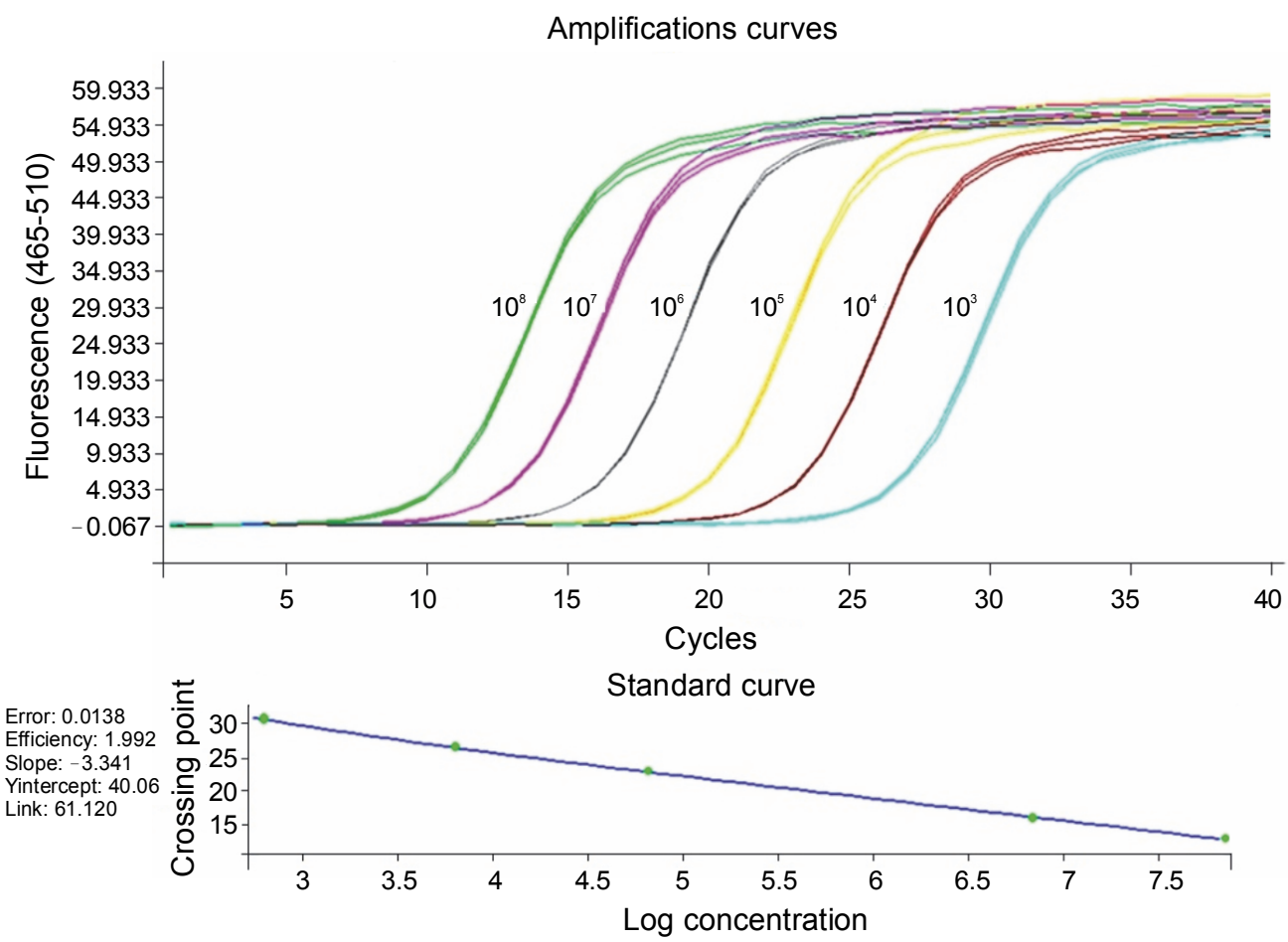

Fig. 3. Standard curve of RT-qPCR assay for ASBVd detection and quantification; upper: the assay amplification kinetics performed accurately enough to quantify ASBVd levels in different samples of avocado crops (slope $=-3.341$ and efficiency $=1.992$ ); the lines green, pink, gray, yellow, brown and turquoise represents standard serial dilutions from $6.37 \mathrm{E}+08$ to $6.37 \mathrm{E}+03$ copies/ $\mu \mathrm{l}$; the $\mathrm{X}$-axis shows the amplification cycles and the Y-axis the intensity of fluorescence from SYBR Green dye used into RT-qPCR assay; bottom: linear regression of serial dilution for ASBVd standard, parameters in the left are the error produce in the triplicate of the sample; the efficiency of amplification which one if it is close to 2 theoretically duplicate the product amplified; slope of the linear regression which one if it is close to - 3.332 theoretically means that the dilutions have a good performance; graphics in the right shows $\mathrm{X}$-axis is the log of concentration of plasmid and the Y-axis is the crossing point from each standard dilution 
Table 2. Limit of Detection (LOD) comparison between RT-PCR and RT-qPCR for ASBVd detection using serial dilution of 2 quantified samples (A and $\mathrm{B}$ ) with different genome viroid loads (A: $3.41 \mathrm{E}+02$ copies/ $\mu \mathrm{l}$ and $\mathrm{B}: 1.78 \mathrm{E}+05$ copies/ $\mu \mathrm{l}$ of viroid genome); the results show that the RT-qPCR was more sensitive than RT-PCR

\begin{tabular}{|c|c|c|c|c|c|c|}
\hline \multirow[b]{2}{*}{ Dilution } & \multicolumn{3}{|c|}{ Sample A } & \multicolumn{3}{|c|}{ Sample B } \\
\hline & $\mathrm{Cp}^{\mathrm{a}}$ & $\begin{array}{l}\text { RT-qPCR }{ }^{b} \text { concentration } \\
(\text { copies } / \mu l)\end{array}$ & $\begin{array}{l}\text { RT-PCR } \\
\text { result }\end{array}$ & $\mathrm{Cp}^{\mathrm{a}}$ & $\begin{array}{l}\text { RT-qPCR }{ }^{b} \text { concentration } \\
(\text { copies } / \mu \mathrm{l})\end{array}$ & $\begin{array}{l}\text { RT-PCR } \\
\text { result }\end{array}$ \\
\hline $10^{0}$ & 30.15 & $3.41 \mathrm{E}+02$ & negative & 21.12 & $1.78 \mathrm{E}+05$ & positive \\
\hline $10^{-1}$ & 33.02 & $4.68 \mathrm{E}+01$ & negative & 24.55 & $1.65 \mathrm{E}+04$ & positive \\
\hline $10^{-2}$ & 35.42 & $8.83 \mathrm{E}+00$ & negative & 28.02 & $1.50 \mathrm{E}+03$ & positive \\
\hline $10^{-3}$ & 0 & 0 & negative & 31.98 & $9.59 \mathrm{E}+01$ & negative \\
\hline $10^{-4}$ & 0 & 0 & negative & 34.84 & $1.32 \mathrm{E}+01$ & negative \\
\hline $10^{-5}$ & 0 & 0 & negative & 0 & 0 & negative \\
\hline
\end{tabular}

a - crossing point: the crossing point is the cycle at which fluorescence achieves a defined threshold (it corresponds to the cycle at which a statistically significant increase in fluorescence is first detected); b - Reverse Transcription Real Time Polymerase Chain Reaction; c - Reverse Transcription Polymerase Chain Reaction

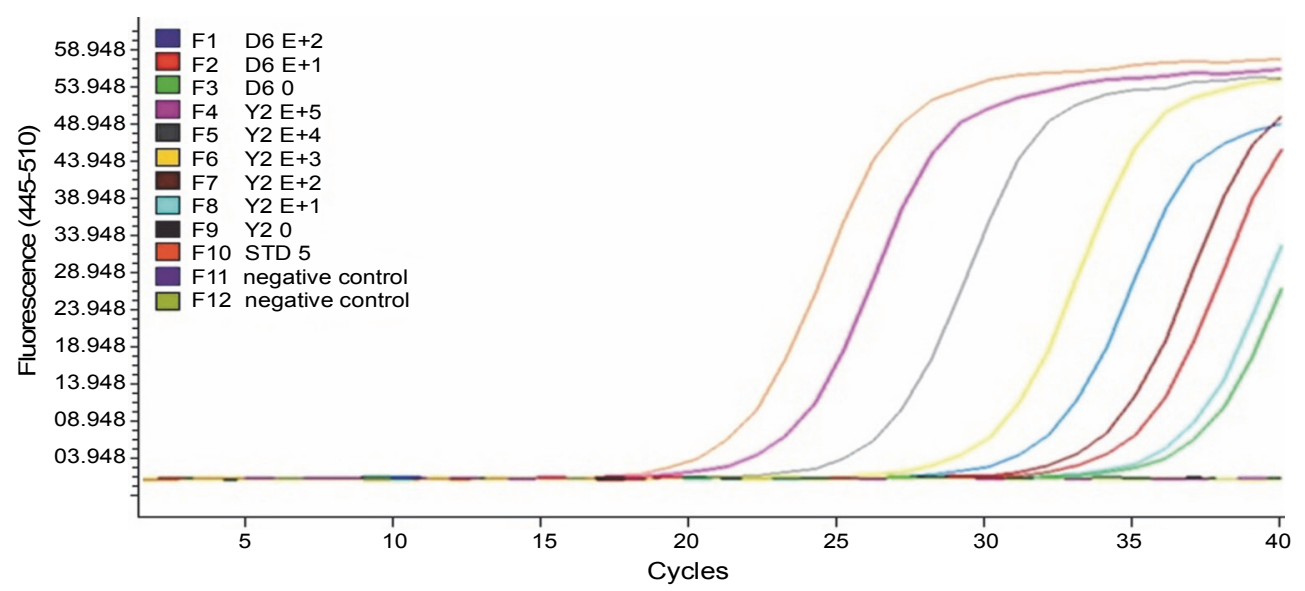

Fig. 4A. Amplification of serial dilution of two samples of ASBVd to determine the lower detection limit. Kinetic amplification of serial dilution of higher (B: $1.78 \mathrm{E}+05 \mathrm{copies} / \mu \mathrm{l})$ and lower sample (A: $3.41 \mathrm{E}+02 \mathrm{copies} / \mu \mathrm{l})$

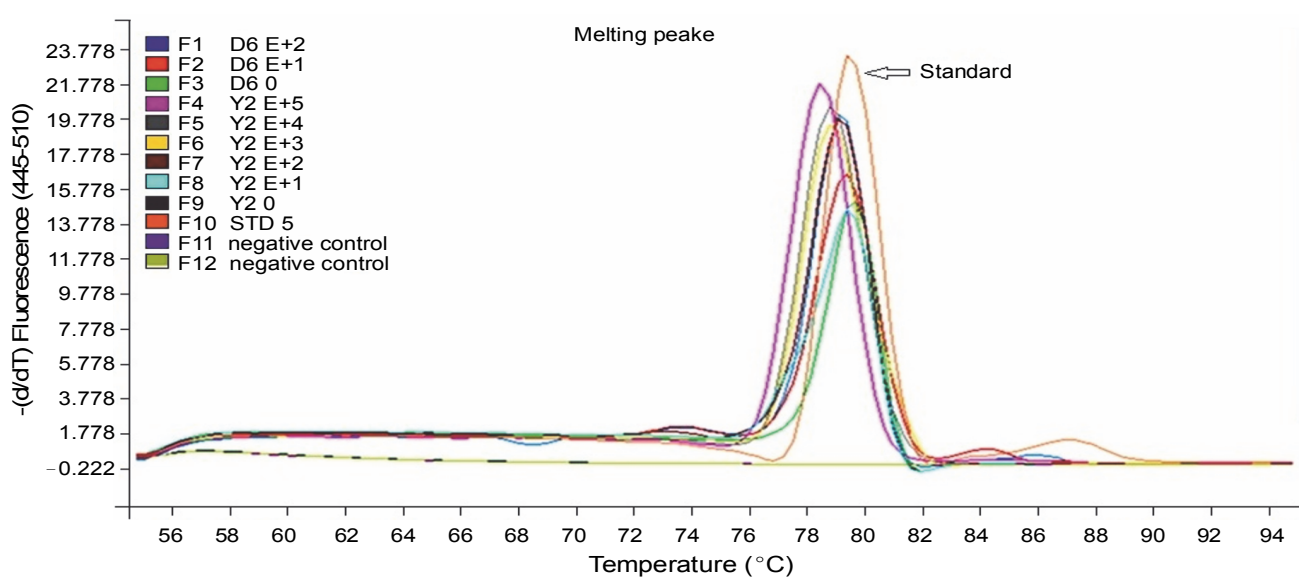

Fig. 4B. Melting curve analysis shows a specific product for ASBVd between 78.46 and $79.52^{\circ} \mathrm{C}$ possibly due to a small internal change in the sequence; blue line - sample A: $3.41 \mathrm{E}+02$ copies $/ \mu \mathrm{l}$; red line - sample A: $3.41 \mathrm{E}+01 \mathrm{copies} / \mu \mathrm{l}$; green line - sample A: 3.41 copies/ $\mu \mathrm{l}$; pink line - sample B: $1.78 \mathrm{E}+05$ copies/ $\mu \mathrm{l}$; gray line - sample B: $1.78 \mathrm{E}+04$ copies/ $\mu \mathrm{l}$; yellow line - sample B: $1.78 \mathrm{E}+03$ copies/ $\mu \mathrm{l}$; brown line - sample B: $1.78 \mathrm{E}+02$ copies/ $\mu \mathrm{l}$; turquoise line - sample B: $1.78 \mathrm{E}+01 \mathrm{copies} / \mu \mathrm{l}$; dark green line - sample B: 1.78 copies/ $\mu$; orange line - standard $6.27 \mathrm{E}+05$; violet and medium green lines - negatives control (water and RNA from ASBVd-free plant, respectively) 


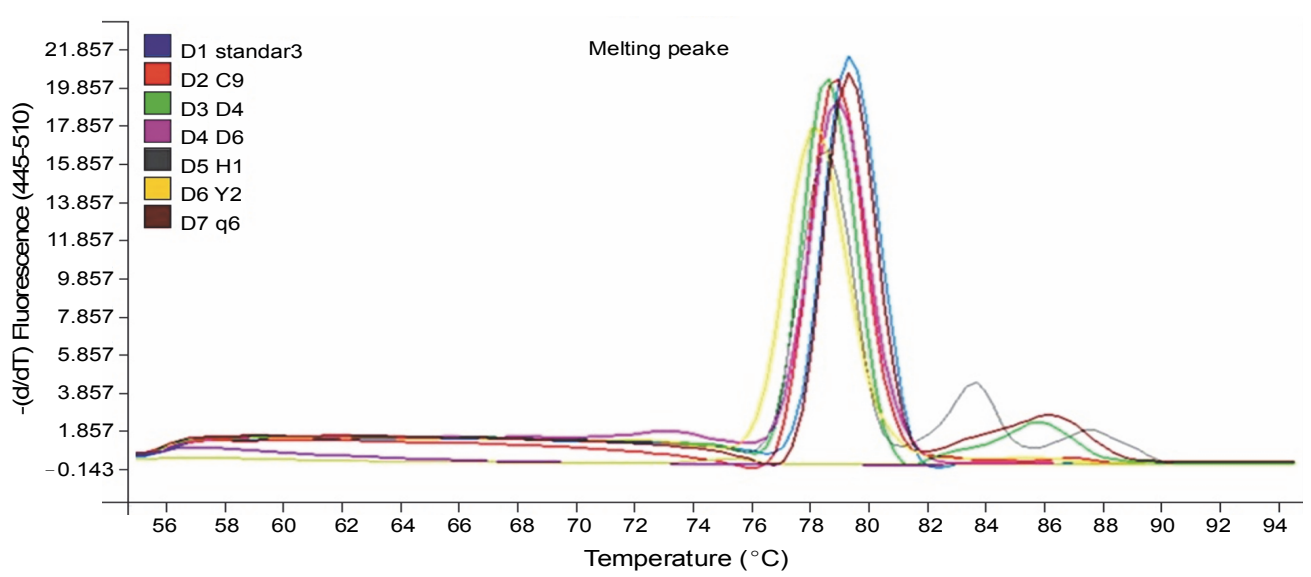

Fig. 5A. Amplification by RT-qPCR of 380 avocado trees (leaves samples) for ASBVd detection; kinetic amplification of some positive samples

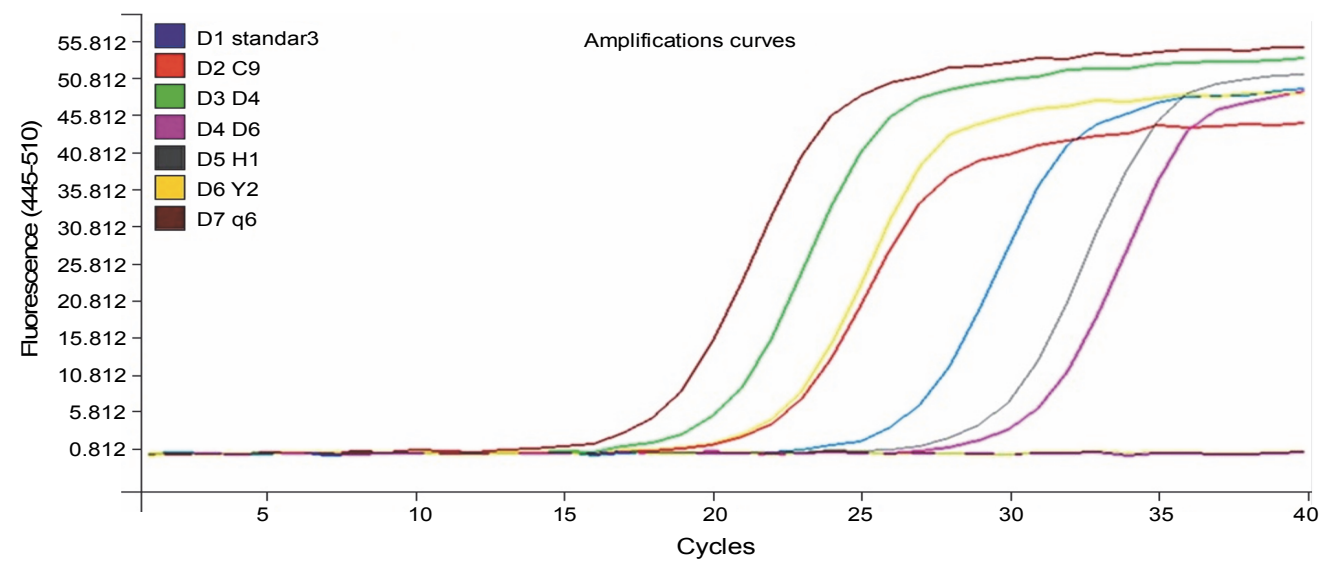

Fig. 5B. Melting curve analysis showing the specific product for ASBVd between $78.33^{\circ} \mathrm{C}$ and $79.46^{\circ} \mathrm{C}$ may be due to a small internal change in the sequence; blue line: standard $6.37 \mathrm{E}+03$ copies/ $\mu$; red line: sample C9; green line: sample D4; pink line: sample D6; gray line: sample H1; yellow line: sample Y2 and brown line: sample q6; violet and medium green lines: negatives control (water and RNA from ASBVd-free plant, respectively)

\section{Results}

\section{Detection of ASBVd by RT-PCR and RT-qPCR}

Detections of ASBVd from symptomatic avocado leaves by RT-PCR and RT-qPCR were carried out using primers previously developed by Schnell and coworkers, (1997) and primers developed in the current study (Table 1). Four symptomless avocado leaves tested positive for ASBVd in RT-qPCR reaction and were further confirmed by sequencing.

The RT-qPCR primers designed from a full circular viroid genome ( $249 \mathrm{bp}$ ) were able to detect viroid samples better than RT-PCR, avoiding false negatives. The specific amplifications of the target RNA of ASBVd (Fig. 1A) and $\beta$-actin (Fig. 1B) were confirmed by agarose gel electrophoresis. The melting curve analysis showed the absence of nonspecific peaks (Fig. 2), and a specific peak $(\mathrm{TM})$ of positive samples $\left(79.3 \pm 1^{\circ} \mathrm{C}\right)$ was determined.

\section{Detection limit and the standard curve}

The linear range of quantification of the RT-qPCR assay for ASBVd was determined by using 10 -fold serial dilutions of the standard (range from $6.37 \mathrm{E}+03$ to $6.37 \mathrm{E}$ +08 copies $/ \mu \mathrm{l}$ ). The standard curve (Fig. 3.) covered a linear range of 5 orders of magnitude. The slope $(-3.341)$ and the correlation coefficient $(\mathrm{R} 2=0.986)$ of the standard curve showed that this assay could be used to quantify the target RNA in infected avocado plants.

From serial dilutions of 2 samples (A: $3.41 \mathrm{E}+02$ copies $/ \mu \mathrm{l}$; B: $1.78 \mathrm{E}+05$ copies $/ \mu \mathrm{l})$, the RT-qPCR assay was able to detect the amplification in 1E-024 and 1E-04 
Table 3. The results of positive amplification for ASBVd by RT-qPCR in avocado leaves. The melting curve analysis showed a melting temperature (TM) in a range between $78.33^{\circ} \mathrm{C}$ and $79.46^{\circ} \mathrm{C}$ (the difference in the TM was probably due to a small nucleotide change in the viroid sequence)

\begin{tabular}{c|c|c|c}
\hline Positive samples & $\mathrm{Cp}^{\mathrm{a}}$ & $\begin{array}{c}\text { Viroid concentration } \\
(\text { copies } / \mu \mathrm{l})\end{array}$ & $\mathrm{TM}^{\mathrm{b}}$ \\
\hline $\mathrm{D} 4$ & 19.92 & $4.52 \mathrm{E}+5$ & 78.77 \\
\hline $\mathrm{D} 6$ & 30.58 & $6.40 \mathrm{E}+2$ & 79.13 \\
\hline $\mathrm{C} 9$ & 21.93 & $1.13 \mathrm{E}+5$ & 79.1 \\
\hline $\mathrm{q} 6$ & 18.06 & $1.63 \mathrm{E}+6$ & 79.46 \\
\hline $\mathrm{H} 1$ & 29.47 & $1.12 \mathrm{E}+3$ & 78.68 \\
\hline $\mathrm{Y} 2$ & 21.93 & $1.13 \mathrm{E}+5$ & 78.33 \\
\hline
\end{tabular}

$\mathrm{a}$ - crossing point; $\mathrm{b}$ - melting temperature: the melting temperature is defined as the temperature at which $50 \%$ of the DNA helices are dissociated and the fluorescence decays

dilutions (samples A and B, respectively), while the RTPCR assay detected the viroid in the 1E-02 dilution (sample B) only. The results showed that the detection sensitivity of RT-qPCR assay was about 100 times higher than the RT-PCR (Table 2) and it also detected the lowest viroid titer. This RT-qPCR assay enabled us to detect as few as 8.8 copies/ $\mu 1$ of the ASBVd in avocado total RNA extracts. The amplification kinetics (Fig. 4A) and the melting curve (Fig. 4B) confirmed the specific amplification of the ASBVd.

\section{Detection of ASBVd from avocado leaves}

Detection of ASBVd by the RT-qPCR assay was carried out using the total RNA isolated from 380 avocado leaves. Six samples tested positive for ASBVd (Fig. 5A and Table 3 ), the melting curve analysis of the positive samples showed a $\mathrm{Tm}$ between $78.33^{\circ} \mathrm{C}$ and $79.46^{\circ} \mathrm{C}$ (Fig. 5B). The difference in the melting temperature was probably due to a small change in the nucleotide sequences of viroids.

\section{Discussion}

The need for sensitive, rapid, and reliable methods of detection of pathogens including microbes, viruses, and viroids is critical for the health of many plants (Candresse et al., 1998; Saponari et al., 2013). In this study, RT-qPCR detected the avocado sunblotch viroid in infected samples with viroid levels that has been too low to be detected for routine methods (conventional RTPCR, Nucleic acid spot hybridization-NASH, etc.). These results highlight a higher sensitivity and specificity of RT-qPCR, which makes the detection and quantification of ASBVd possible already in early infections of avocado trees. The 100 -fold increase in the sensitivity gained by using RT-qPCR is likely to increase the effectiveness of certification programs that require the initial vegetative material of avocado to be free from ASBVd.

A careful selection of primers has proven to be the most effective approach to increase the sensitivity of the method, compared with RT-PCR (Bustin et al., 2009; Zhang et al., 2013a; Zhang et al., 2013b). When using primers reported by Schnell and coworkers (1997) for RT-qPCR, 4 of the 10 positive samples detected by RTPCR were reported as negative by the RT-qPCR and further sequencing. The RT-qPCR method allowed obtaining more accurate results and detect lower virus titer ( 8.8 copies $/ \mu \mathrm{l}$ ), when compared to conventional RT-PCR.

Changes in single nucleotides in viroid genome sequences can result in altered symptoms in avocado trees (Schnell et al., 2001). By sequencing, we determined that changes in nucleotide sequences are also responsible for the differences in melting temperatures observed in RT-qPCR (C to $\mathrm{T}$ in position 202 and $\mathrm{G}$ to $\mathrm{A}$ in position 207). Our findings were similar to the results reported by Schnell and coworkers (2001) and Cambrón (2011), and variations require further studies. Based on the sensitivity, specificity, accuracy, and repeatability of this RT-qPCR assay, it is suggested that its employment for routine diagnostics in breeding programs might decrease the viroid incidence in avocado crops and its further accumulation in plants. 


\section{Acknowledgments}

Financial support was provided by the grant PCyT C16 PIPEI Camposol S.A. of Science and Technology Program - FINCyT (Funds for Innovation, Science and Technology) and Research and Development Fund for Competitiveness - INNOVATE FIDECOM. We thank The Peruvian National Council of Science, Technology, and Innovation (CONCYTEC) for its efforts in developing a scientific research in Peru, Biotec C.M.C. research center and Camposol part of D\&C Group for the study design, data collection, analysis, and for investing in this biotechnology research. A professional writer assisted with the grammar, formatting, and editing of the text.

\section{Ethics statement}

This study was approved by the Research and Development Committee of Camposol S.A. The assay did not involve endangered or protected species and hence no specific permissions were required.

\section{References}

Allen R.N., Dale J.L. (1981) Application of rapid biochemical methods for detecting avocado sunblotch disease. Ann. Appl. Biol. 98(3): 451-461.

Bernard L., Duran-Vila N. (2006) A novel RT-PCR approach for detection and characterization of citrus viroids. Mol. Cell Probes. 20: 105-113.

Boonham N., Gonzàlez Perez L., Mendez M.S., Peralta L.E., Blockley A., Walsh K., Barker I., Munford R.A. (2004) Development of a real-time RT-PCR assay for the detection of Potato spindle tuber viroid. J. Virol. Meth. 116: 139-146.

Botermans M., van de Vossenberg B.T., Verhoeven J.T., Roenhorst J.W., Hooftman M., Dekter R., Meekes E.T. (2013) Development and validation of a real-time RT-PCR assay for generic detection of Pospiviroids. J. Virol. Meth. 187(1): 43-50.

Brunner A.M., Yakovlev I.A., Strauss S.H. (2004) Validating internal controls for quantitative plant gene expression studies. BMC Plant Biol. 4: 14.

Bustin S.A., Benes V., Garson J.A., Hellemans J., Huggett J., Kubista M., Mueller R., Nolan T., Pfaffl M.W., Shipley G.L., et al. (2009) The Miqe guidelines: Minimum information for publication of quantitative real-time $P C R$ experiments. Clin. Chem. 55: 611-622.

Candresse T., Hammond R.W., Hadidi A. (1998) Detection and identification of plant viruses and viroids using polymerase chain reaction (PCR). [in:] Control of plant virus diseases. Ed. Hadidi A., Khetarpal R.K., Koganezawa K. APS Press: St. Paul, MN, USA: 399-416.

Chang S., Puryear J., Cairney J. (1993) A simple and efficient method for isolating RNA from Pine trees. Plant Mol. Biol. Report. 11(2): 113-116.

Dale J., Symons R., Allen R. (1982). Avocado Sunblotch viroid. VMI/AAB. Descriptions of Plant Viruses. No. 254. Available: http://www.dpvweb.net/dpv/showdpv.php?dpvno $=254$. Accessed: 11 November, 2013.
Daròs J.A., Marcos J.F., Hernández C., Flores R. (1994) Replication of Avocado Sunblotch viroid: Evidence for a symmetric pathway with two rolling circles and hammerhead ribozyme processing. Proc. Natl. Acad. Sci. USA 91: 12813-12817.

Desjardins P.R. (1987) Avocado Sunblotch. [in:] The Viroids. New York. Plenum Press: 299-313.

Fekih H.I., Roussel S., Kummert J., Fakhfakh H., Marrakchi M., Jijakli M.H. (2006) Development of a rapid Rt-PCR test for the detection of Peach latent mosaic viroid, Pear blister canker viroid, Hop stunt viroid and Apple scar skin viroid in fruit trees from Tunisia. J. Phytopathol. 154: 217-223.

Flores R., Daròs J.A., Hernández C. (2000a) The Avsunviroidae family: viroids containing hammerhead ribozymes. Adv. Virus Res. 55: 271-323.

Flores R., Delgado S., Gas M.E., Carbonell A., Molina D., Gago S., De la Pena M. (2004) Viroids: the minimal non-coding RNAs with autonomous replication. FEBS Lett. 567:42-48.

Flores R., Randless J.W., Bar-Joseph M., Diener T.O. (2000b) Subviral agents: Viroids. [in:] Virus Taxonomy, Seventh Report of the International Committee on Taxonomy of Viruses. Ed. van Regenmortel M.H.V., Fauquet C.M., Bishop D.H.L., Carstens E.B., Estes M.K., Lemon S.M., McGeoch D.J., Maniloff J., Mayo M.A., Pringle C.R., Wickner R.B. Academic Press, San Diego, CA: 1009-1024.

Grozo J., Riva L., Catacora B. (2006) Palto: Producto en ascenso. Informacción Agraria 39: 8-9.

Hajizadeh M., Navarro B., Bashir N.S., Torchetti E.M., Di Serio F. (2012) Development and validation of a multiplex RT-PCR method for the simultaneous detection of five grapevine viroids. J. Virol. Meth. 179(1): 62-69.

Hutchins C., Rathjen P.D., Forster A.C., Symons R.H. (1986) Self-cleavage of plus and minus RNA transcripts of Avocado Sunblotch viroid. Nucl. Acids Res. 14: 3627-3640.

Lemus G., Ferreyra R., Gil P., Maldonado P., Toledo C., Barrera C., Celedón J. (2005) El cultivo del palto. La Cruz, Chile. Instituto de Investigaciones Agropecuarias. Boletín INIA No. 129: p. 76

Luigi M., Luison D., Tomassoli L., Faggioli F. (2011) First report of Potato spindle tuber and Citrus exocortis viroids in Cestrum spp. in Italy. New Dis. Rep. 23: 4.

Mackenzie D., McLean M., Mukerji S., Green M. (1997) Improved RNA extraction from woody plants for the detection of viral pathogens by reverse transcription-polymerase chain reaction. Plant Dis. 81: 222-226.

Mathews D., Heick J., Dodds J. (1997) Detection of Avocado Sunblotch viroid by polymerase chain reaction (PCR). California Avocado Society Yearbook 81: 91-96.

Monger W., Tomlinson J., Booonham N., Marn M.V., Plesko I.M., Molinero-Demilly V., Tassus X., Meekes E., Toonen M., et al. (2010) Development and inter-laboratory evaluation of real-time PCR assays for the detection of pospiviroids. J. Virol. Meth. 169(1): 207-210.

Palukaitis P., Hatta T., Alexander D.M., Symons R.H. (1979) Characterization of a viroid associated with Avocado Sunblotch disease. Virology 99: 145-151. 
Parisi O., Lepoivre P., Jijakli M.H. (2011) Development of a quick quantitative real-time PCR for the in vivo detection and quantification of Peach latent mosaic viroid. Plant Dis. 95: 137-142.

Rizza S., Nobile G., Tessitori M., Catara A., Conte E. (2009) Real time RT-PCR assay for quantitative detection of $C^{i}$ trus viroid III in plant tissues. Plant Pathol. 58: 181-185.

Roenhorst J., Jansen C., Kox L., de Haan E., van de Bovenkamp G., Boonham N., Fisher T., Mumford R. (2005). Application of real-time RT-PCR for large-scale testing of potato for Potato spindle tuber pospiviroid. EPPO Bull. 35: 133-140.

Ruiz-Ruiz S., Moreno P., Guerri J., Ambros S. (2007) A realtime RT-PCR assay for detection and absolute quantification of Citrus tristeza virus in different plant tissues. J. Virol. Meth. 145: 96-105.

Saponari M., Loconsole G., Liao H.H., Jiang B., Savino V., Yokomi R.K. (2013) Validation of high-throughput real time polymerase chain reaction assays for simultaneous detection of invasive citrus pathogens. J. Virol. Meth. 193(2): 478-486

Schnell R., Olano C.T., Fuhn D. (2001) Detection of Avocado Sunblotch viroid variants using fluorescent single-strand conformation polymorphism analysis. Electrophoresis 22: 427-432.

Schnell R.J., Kuhn D.N., Ronning C.M., Harkins D. (1997) Application of RT-PCR for Indexing Avocado Sunblotch Viroid. Plant Dis. 81(9): 1023-1026.

Semancik J.S., Szychowski J.A. (1994) Avocado Sunblotch disease: A persistent viroid infection in which variants are associated with differential symptoms. J. Gen. Virol. 75: 1543-1549.

Suzuki Y., Makino A., Mae T. (2001) An efficient method for extraction of $R N A$ from rive leaves at different ages using benzyl chloride. J. Exp. Bot. 52(36): 1575-1579

Tessitori M., Rizza S., Reina A., Catara V. (2005) Real-time RT-PCR based on Sybr-Green I for the detection of citrus exocortis and citrus cachexia disease. [in:] Proceedings of the 16th Conference of the International Organization of Citrus Virologists, 2004. Ed. Hilf M.E., Duran-Vila N., Rocha-Peña M.A. Riverside, CA, USA: IOCV: 456-459.

Vargas C.O., Querci M., Salazar L.F. (1991) Identificación y estado de diseminación del viroide del manchado solar del palto (Persea americana L.) en el Perú y la existencia de otros viroides en palto. Fitopatología 26: 23-27.

Wallace J., Drake R. (1962) A high rate of seed transmission of Avocado Sunblotch from symptomless trees and the origin of such trees. Phytopathology 52: 237-241.

Zhang P., Mar T.T., Liu W., Li L., Wang X. (2013a) Simultaneous detection and differentiation of Rice black streaked dwarf virus (RBSDV) and Southern rice black streaked $d$ warf virus (SRBSDV) by duplex real time RT-PCR. Virol. J. 10: 24 .

Zhang S., Zhang D., Liu Y., Luo X., Cheng J. (2013b) Development of a real-time RT-PCR method for rapid detection and quantification of southern Rice black-streaked dwarf virus in rice. J. Plant. Pathol. Microb. 4: 187. 